\title{
The Effect of Replacement of Sorghum with Millet on Broilers Performance
}

\author{
Aladeen Ali Mohamed Adam¹, Omer Massaad Elbashier² \\ ${ }^{1,2}$ Sudan University of Science and Technology
}

\begin{abstract}
This study was carried out at the farm of the College of Animal Production of Science and Technology, Sudan University of Science and Technology at Hillat Kuku. The experiment was conducted to evaluate the effect of replacement of Sorghum with Millet and its effect on broilers in the finisher performance included: Feed consumption, body weight gain, feed conversion ratio (FCR) and mortality. One hundred and twenty Arbor Acre commercial hybrid broiler chicken in age (28) days in this study were used. The Chicks were randomly distributed in 4 treatments experimental groups, each group has 3 replicates of 10 chicks. Millet replaced sorghum: 0\% $20 \%-40 \%-60 \%$ in group $a, b, c$ and $d$ respectively. The results showed that there is no significant difference among experimental groups on broilers performance when replaced the Sorghum by Millet in finisher diet. Statistically a highly significant difference $(p<0.01)$ between groups for (FCR). Millet improved feed efficiency. The adding of millet did not show any negative effect in the stock health and there is no any mortality throughout the experiment period.
\end{abstract}

Keywords: Sorghum, Millet, Feed Consumption, Mortality, Body Weight Gain and Feed Conversion Ratio

\section{Introduction}

The high cost of broiler feeds has stimulated an increasing demand for alternative feed stuffs, including pearl millet (Pennisetumglaucum). Varieties of pearl millet have been shown to be at least equivalent to maize and superior to sorghum in terms of yield and nutritive value. Such comparisons of the feeding value of the pearl millet grain have never been undertaken. Pearl millet has been identified as a suitable alternative to sorghum in low rainfall and sandy areas. Pearl millet is native to the western edges of the Sahara desert and is commonly grown as a forage and grain crop inarid areas of Africa and India. It grows well under conditions of erratic rain, high temperatures, and poor soil conditions. Additionally, pearl millet is a fast-growing crop. $\{1\}$, however, is resistant to fungal diseases. Previous research with this hybrid indicates that pearl millet had a comparable TMEn value $(3,300$ to $3,448 \mathrm{kcal} / \mathrm{kg})$ and higher protein content (12 to $14 \%$ ) than corn, dry matter: $90 \%$. The Nutrient Content of Pearl Millet, metabolizable energy, 3240 $\mathrm{kcal} / \mathrm{kg}$ (1470 kcal/lb), Crude protein 12.0\%, Methionine $0.28 \%$, Cysteine $0.24 \%$, Lysine $0.35 \%$, Tryptophan $0.20 \%$, Threonine $0.44 \%$, Crude fat $4.2 \%$, Crude fiber $1.8 \%$ Ash $2.5 \%$, Calcium $0.05 \%$, Total phosphorus $0.30 \%$, and Nonphytate phosphorus: $0.10 \% .\{10\}$.

The performance and carcass yield of broilers fed diets containing up to $50 \%$ ground pearl millet were equivalent or better than those of broilers fed typical corn-soybean meal diets $\{5\}$.Pearl millet (PM) has higher protein content, but lower apparent metabolizable energy (AMEn) than corn for broilers. However, according to $\{10\}$, the AMEn of modern PM hybrids is very similar to that of corn. Pearl millet can be added at $40 \%$ to pre-starter and starter iso-nutrient in broiler diets (Gomes et al., 2008) with no harm to their performance. $\{3\}$, concluded that it was feasible to include $50 \% \mathrm{PM}$ in iso-nutrient diets, and $\{9\}$, asserted that it is profitable to replace $100 \%$ corn by PM in the diets of broilers of all phases. According to $\{1\}$, broiler performance was superior when corn was completely replaced by PM in diets. On the other hand, with complete and isometric replacement of corn by different millet types, $\{11\}$, described worse weight gain and feed conversion ratio of 21 - and 42-days-old broilers. $\{15\}$ observed a weight of 580 $\mathrm{g}$ per bird in broiler chicks, fed rations with lower rate of pearl millet inclusion (36.80 per cent) that was significantly higher $(\mathrm{P}<0.05)$ than the one fed with wheat $(537 \mathrm{~g}$ per bird $)$ and sorghum (512 g per bird). In groups fed with cereals at high inclusion rate (55.20 per cent), pearl millet group recorded maximum body. In an experiment with broilers to study the effect of pearl millet inclusion replacing maize up to 4 weeks from 1 st week of age with isocaloric and isonitrogenous diet, $\{14\}$ registered a marginally higher weight gain of $390 \mathrm{~g}$ per bird in pearl millet group compared to $383 \mathrm{~g}$ per bird in maize group. The feed intake in the pearl millet group was $815 \mathrm{~g}$ whereas it was $899 \mathrm{~g}$ in maize fed group.

Research indicates that feeding millet can improve starch digestibility $\{8\}$ and is not detrimental to feed utilization. $\{16\}$ found that both 50 and 100 per cent replacement groups could not exert any significant influence on body weight and feed intake but, birds with 50 per cent ground and unground pearl millet recorded better body weights.

when millet incorporated into broiler diets at low levels, given that millet is relatively small (2 to $3 \mathrm{~mm}$ ) in size and that supplies of this grain will be limited and seasonal as cultivation of this pearl millet hybrid increases over the next few years, it may be feasible to incorporate modest levels of pearl millet grain into broiler diets in whole form. Additionally, few feed mills have post grinding storage capacity for more than 1 grain; therefore, the goal of the present research was to determine if pearl millet grain could be incorporated into pelleted broiler diets without adversely affecting pellet quality or broiler performance. Pearl millet has been shown to be a suitable feed ingredient for poultrydiets. Up to $50 \%$ pearl millet can be added to broiler diets without adversely affecting performance. Pearl millet is higher in methionine than corn, alleviating some of the need for synthetic methionine supplementation in organic poultry diets. $\{12\}$. 


\section{International Journal of Science and Research (IJSR) \\ ISSN (Online): 2319-7064 \\ Index Copernicus Value (2013): 6.14 | Impact Factor (2015): 6.391}

\section{Materials and Methods}

\section{Experimental Location}

The study was carried out at the farm of the College of Animal Production of Science and Technology, Sudan University of Science and Technology at Hillat Kuku, during the period of 22-11-2013 to 2-1-2014

\section{Experimental Diets}

The composition of the starter and finisher diets is shown in Table 1. Pearl millet was purchased from the local marketFour (1) diets were formulated for each of the experiments. Diet A served as Control 0\%. Diets B, C and D contained $20 \%, 40 \%$ and $60 \%$ respectively.

Table 1: Composition of the starter and finisher diets

\begin{tabular}{|c|c|}
\hline$\%$ & \\
\hline $\mathbf{2 4}$ & Protien \\
\hline $\mathbf{4 . 1}$ & Crude Fiber \\
\hline $\mathbf{1 . 0 0}$ & Calcium \\
\hline $\mathbf{3 7 .}$ & Phosphor \\
\hline $\mathbf{1 . 3 4}$ & Lysine \\
\hline $\mathbf{5 0 .}$ & Methionine \\
\hline kcal $\backslash \mathrm{kg} 3 \mathbf{3 1 0 0}$ & Metabolizable Energy \\
\hline
\end{tabular}

\section{Experimental Birds}

One hundred and twenty (120) day old broiler chicks of Statistical Analyses

Data collected were subjected to analyses of variance (ANOVA) and Duncan's Multiple Range Test (DMRT) was used to separate means that were significantly different.

\section{Results}

mixed sexes Arbaicher strain were used for the starter phase in a completely randomized design. The birdswere divided in to four (4) treatments with thirty (30) birds each. Three replicates formed each treatment with ten (11) birds per replicate. The chicks were brooded on deep litter using 100 watt bulbs, flat plastic feeders and shallow drinkers for the first two (2) weeks of the experiment. The birds were fed starter mash diets for four (4) weeks. Feed and water were provided ad-libitum. The birds were vaccinated against gumboro disease at the second and fourth weeks of age as first and second doses respectively. In the finisher phase a total of 120 Arbaicher strain of broiler birds were used in a completely randomized design. The birds used were obtained at the end of a starter phase experiment using the same test ingredient levels. After the starter phase experiment, the birds were re-randomized and fed on common ration for one week to serve as the adjustment period. The birds were divided into 4 treatments which consist of 3 replicates per treatment with 10 birds per replicate for two weeks.

\section{Data Collection}

Data on feed left over and body weights were recorded weekly. Observation on mortality was done daily. Feed intake, weight gain and feed conversion ratio were calculated at the end of each of the phases.

The results of the performance of broilers fed the various levels of whole millet in diet are shown in Table 2, 3 and 4 The results have shown that there is no significant differences between the birds fed the control diet and the whole millet diets in feed conversion

Table 2: Effect Adding Millet on Weekly Feed Consumption

\begin{tabular}{|l|c|c|c|c|c|}
\hline Weeks & $\mathrm{A}$ & $\mathrm{B}$ & $\mathrm{C}$ & $\mathrm{D}$ & Level of Significance \\
\hline & & & & & $\mathrm{Sig}$ \\
\hline Firest Week & Mean \pm std & Mean \pm std & Mean \pm std & Mean \pm sd & NS \\
\hline Second Week & $.97 \pm .042$ & $1.0 \pm .100$ & $.97 \pm .02$ & $.90 \pm .03$ & NS \\
\hline The values are means \pm standard deviation, they are replicate of 5 birds for each group. \\
Significant at $(\mathrm{P}<0.05) . * *=$ Significant at $(\mathrm{P}<0.01)$. NS=Not Significant. \\
Significant at $(\mathrm{P}<0.05) . * *=$ Significant at $(\mathrm{P}<0.01) . \mathrm{NS}=$ Not Significant. \\
$\mathrm{a}, \mathrm{b}, . .=$ means with in the same row followed by different superscript are significantly different
\end{tabular}

Table 3: Effect Adding Millet on Weekly Feed Conversion






\section{International Journal of Science and Research (IJSR) \\ ISSN (Online): 2319-7064}

Index Copernicus Value (2013): 6.14 | Impact Factor (2015): 6.391

Significant at $(\mathrm{P}<0.05) .{ }^{*}=$ Significant at $(\mathrm{P}<0.01) . \mathrm{NS}=$ Not Significant.

$\mathrm{a} b, . .=$ means with in the same row followed by different superscript are significantly different

Table 4: Effect Adding Millet on Weekly Weight Gain

\begin{tabular}{|c|c|c|c|c|c|}
\hline $\begin{array}{ll}\text { IParameters } & \text { Groups } \\
\end{array}$ & $\mathrm{A}(\%)$ & B (\%) & $\mathrm{C}(\%)$ & $\mathrm{D}(\%)$ & Level of Significance \\
\hline Number of Birds & 30 & 30 & 30 & 30 & \\
\hline Duration / days & 15 & 15 & 15 & 15 & \\
\hline Feed Intake & $.85 \pm .71$ & $.95 \pm .10$ & $.96 \pm .09$ & $.86 \pm .01$ & NS \\
\hline Weight Gain & $.63 \pm .12$ & $.57 \pm .07$ & $.63 \pm .03$ & $.66 \pm .03$ & NS \\
\hline Feed Conversion Ratio & $1.5 \pm .25$ & $1.7 \pm 0.50$ & $1.5 \pm .10$ & $1.3 \pm .11$ & $*$ \\
\hline Mortality & 1 & 0 & 0 & 0 & NS \\
\hline $\begin{array}{l}\text { Cost of production of one kilogram of broiler } \\
\text { using millet in Sudanese pounds }\end{array}$ & 20.3 & 20 & 19.6 & 1 & $\begin{array}{l}\text { Average } \\
18.075\end{array}$ \\
\hline $\begin{array}{l}\text { Cost of production of one kilogram of broiler } \\
\text { using sorghum in Sudanese pounds }\end{array}$ & 18 & 18 & 17.9 & 17 & Average 17.725 \\
\hline \multicolumn{6}{|c|}{$\begin{array}{l}\text { The values are means } \pm \text { standard deviation, they are replicate of } 5 \text { birds for ea } \\
\text { Significant at }(\mathrm{P}<0.05) . * *=\text { Significant at }(\mathrm{P}<0.01) \text {. NS }=\text { Not Significant. } \\
\text { Significant at }(\mathrm{P}<0.05) . * *=\text { Significant at }(\mathrm{P}<0.01) \text {. NS }=\text { Not Significant. } \\
\text { a }, \mathrm{b}, . .=\text { means with in the same row followed by different superscript are sig }\end{array}$} \\
\hline
\end{tabular}

\section{Discussion}

The results of the performance of broilers fed the various levels of whole millet in the diet are shown in Table 2, 3 and 4. There were no significant $(p>0.05)$ differences between the birds fed the control diet and the whole millet diets in the final weight, weight gain and mortality. This may be due to the uniformity in the nutrient content of diets. These results are similar to the results obtained by [5 7] who added millet to feed which adversely affected feed conversion but not body weight of broiler chickens Other published research demonstrated no reductions in growth rate or feed conversion by adding millet at 15 and 30 []ㅡ. Bird age appeared to influence the response of adding millet to feed. In the present study, the addition of $60 \%$ millet to feed does not affect growth rate and feed conversion compared with the control-fed $0 \%$ millet. The reduction in performance may have been partially attributed to nutrient content. These findings are in line with $\{9\}$ who reported that the performance and carcass yield of broilers fed diets containing whole millet were equivalent to those fed a typical corn-soybean meal diet and also similar to the results of $\{3\}$ who reported that the birds fed on millet rates 0,25 , $50,75 \%$ were better or equal to control treatment in live body weight, dressing $\%$, feed conversion ratio and weight increase. While a full replacement of millet lead to the lower in live body weight, dressing percent, feed conversion ratio and weight increase $(\mathrm{p}<0.05)$. The birds fed the $20 \%$ whole millet diet had significantly better total feed consumption per bird and feed conversion ratio. This was similar to the report by $\{8\}$ who stated that the performance and carcass yield of broilers fed diets containing up to $50 \%$ ground pearl millet were equivalent or better than those fed typical cornsoybean meal diets. The use of $20 \%$ whole millet in diets for broilers in the humid tropics, thus seem to be of advantage from this study. The numerical value obtained from the cost of feed per bird in each treatment was similar even though the actual cost of sorghum was $17.725 \mathrm{SP} / \mathrm{kg}$ and millet cost was $18.075 \mathrm{SP} / \mathrm{kg}$. This difference in the cost of feed per bird across the treatment was attributed to the high cost for millet now a days but sometimes its price fall down and become less cheap than the price of sorghum. The mortally of birds was not significantly different between treatments. The mortality recorded during the 2 days of arrival could be attributed to the stress of transportation.

The results showed that there is no significant difference among experimental groups on broilers performance when replaced the Sorghum by Millet in finisher diet. Statistically a highly significant difference $(p<0.01)$ between groups for feed conversion ratio and the adding of millet improved feed efficiency. The adding of millet did not show any negative effect in the stock health and there was no mortality throughout the experimental period.

\section{Acknowledgement}

We would like to thank Sudan University of Science and Technology for their financial support

\section{References}

[1] Baurhoo N, Baurhoo B, Mustafa Af, Zhao X. Comparison of corn-based andcanadian pearl milletbased diets on performance, digestibility, villus morphology, and digestive microbial populations in broiler chickens.Poultry Science; 2011, 90(3):579-586.

[2] Crouch A. N., Grimes J. L., Ferket P. R., Thomas L. N. . Enzyme supplementation to enhance wheat utilization in starter diets for broilers and turkeys. J. Appl. Poult. Res. 1997, 6:147-154.

[3] Davis AJ, Dale NM, Ferreira FJ. Pearl millet as an alternative feed ingredient in broiler diets. The Journal of Applied Poultry Research 2003; 12(2):137-144.

[4] Duncan, D B.; Multiple range and multiple F tests. Biometrics 11:1-42, 1955.

[5] Engberg RM, Hedamenn MS, Jensen BB. The influence of grinding and pelleting of feed on the microbial composition and activity in the digestive tract of broiler chickens. British Poultry Science; 200243(4):569-79.

[6] Gomes PC, Rodrigues MP,Albino LFT, Rostagno HS, Gomes MFM, MelloHHDC, Brumano G. Determinação da composiçãoquímica e energéticadomilheto e suautilizaçãoemrações para frangos de corte de 1 a 21 
dias de idade. RevistaBrasileira de Zootecnia 2008; 37(9):1617-1621.

[7] Hadimani NA, Muralikrishna G, Tharanathan RN, Malleshi NG. Nature of Carbohydrates and proteins in three pearl millet varieties varying in processing characteristics and kernel texture. Journal of Cereal Science;2001 33(1):17-25.

[8] Hidalgo MA, Davis, AJ, Dale NM, Dozier III WA. Use of whole pearl millet in broiler diets. Journal of Applied Poultry Research; 2004, 13(2):229-234.

[9] Klasing KC. Comparative avian nutrition. Effects of particle size and physical form of ration on performance, carcass yield and weight of digestive organs of broiler chickens. ArquivosBrasileirosdeMedicinaVeterinária e Zootecnia; New York: CABI. Publishing; 2000. 56(2):214-221.

[10] Murakami AE, Souza LMG de, Massuda EM, Alves FV, Holanda Guerra R de, Quiles Garcia AF. Economic evaluation and performance of broilers fed with different levels of pearl millet in substitution of corn. ActaScientiarum. Animal Science; 2009, 31(1):31-37.

[11] Rao SVR, Raju MVLN, Reddy MR, Panda AK. Replacement of Yellow Maize with Pearl Millet (Pennisetumtyphoides), Foxtail Millet (Setariaitalica) or Finger Millet (Eleusinecoracana) in broiler chicken diets containing supplemental enzymes. AsianAustralasian Journal of AnimalSciencesoul 2004; 17(6):836-842.

[12] Rostagno HS, Albino LFT, Donzele JL, Gomes PC, Oliveira RF, Lopes DC,Ferreira AS, Barreto SLT. Tabelasbrasileiras para aves e suínos: composição de alimentos e exigênciasnutricionais. Viçosa: UFV/DZO Sas. Sas/Access 9.1 interface to peoplesoft: user's guide. 2004, SAS Inst. Cary: SAS Pub.;

[13] Singh, D.N., P.C. Trappett, T.A. Nagle and R. PerezMaldonado,. Digestibility of pearl millet in broiler diets. Asia pac. J. Clin. Nutr., 13 (suppl): S90.2004Cary, NC, USA.

[14] McGraw-Hill Book Company;.SAS Institute. SAS/STAT User's Guild. SAS Institute Inc.,

[15] Sharma, B.D., V.R. Sadagopan and V.R. Reddy,. Utilization of different cereals in broilers diets. Br. Poult. Sci. 1980, 20:371-37

[16] Satyanarayana Reddy, P.V.V., V. Ravindra Reddy, P.S. Reddy and VijayaBhaskara Rao,. Utilization of bajra (Pennisetumtyphoides) in broilers. Indian J. Poult. Sci., 1991, 26(4): 202-205

[17] Steel RGD, and Torrie JH. Principles and procedures of statistics a biometrical approach. 2nd Edition, New York McGraw- Hill Book Company;.SAS Institute. SAS/STAT 1980 User's Guild. SAS Institute Inc., Cary, NC, USA 